\title{
RANCANG BANGUN DAN UJI KINERJA MESIN PEMIPIL JAGUNG PORTABLE
}

\author{
Agus Susanto Ginting ${ }^{1)}$, Moh.Fikri Pomalingo ${ }^{1)}$, Sjahril Botutihe ${ }^{1)}$ \\ 1) Tim Pengajar pada Program Studi Mesin dan Peralatan Pertanian, Politeknik Gorontalo
}

\begin{abstract}
ABSTRAK
Budidaya jagung di Gorontalo sebesar $60 \%$ dilakukan pada lahan miring. Sistem pertanaman pada lahan miring biasanya menerpakan sistem tanpa oleh tanah. Permasalahan yang dihadapai adalah saat panen dimana dibutuhkan biaya yang besar untuk mengangkut buah jagung dari lahan ke areal pemukiman. Penelitian ini bertujuan untuk merancang mesin pemipil jagung portable yang digandengkan dengan sepeda motor dan memanfaatakn putaran mesin sepeda motor tersebut sebagai sumber tenaga mesin pemipil. Dengan menggunakan mesin yang dirancang diharapkan pemipilan dapat dilakukan dilahan pertanian sehingga beban yang ditransportasikan semakin ringan. Hasil pengujian menunjukkan mesin pemipil mampu berkeja secara fungsional dan struktural. Kinerja mesin terbaik terdapat pada perlakuan dengan kecepatan tinggi dengan kisaran kecepatan putar poros pemipil $5001 \mathrm{rpm}-6500 \mathrm{rpm}$. Pada perlakuan ini diperoleh waktu operasi, effisiensi pemipil, dan kapasitas pemipil berturut-turut sebesar 12,67 detik, $80,10 \%$ dan $282,84 \mathrm{~kg} / \mathrm{jam}$.
\end{abstract}

Kata Kunci : lahan miring, jagung, pemipil portable

\section{DESIGN AND PERFORMANCE ANALYSIS OF PORTABLE CORN THRESHER}

\begin{abstract}
Corn cultivation in Gorontalo by $60 \%$ is done on sloping area. Planting systems on this area usuallydone byminimum tillage. The main problem face is during harvest where expensive cost is need to transport whole corn to the residential area. The aims of this research are to design portable corn thresher and to analysis performance of this machine. Thresher will combine with motorbike as transporter and energy source of thresh system. By using this portable machine expected threshing process can be done in cultivation area. Performance analysis showed portable thresher machine can work in functionally and structurally. The best performance is found in high speed treatment with range speeds $5001 \mathrm{rpm}-6500 \mathrm{rpm}$. In this treatment obtained operating time, threshing efficiency, and threshing capacity 12.67 seconds, $80.10 \%$, and 282, $84 \mathrm{~kg} / \mathrm{hour}$ respectively.
\end{abstract}

Kata Kunci : sloping area, corn, portable thresher

\section{PENDAHULUAN}

Jagung merupakan komoditas utama provinsi Gorontalo. Berdasarkan laporan dari Dinas Pertanian, Tanaman Pangan dan Hortikultura Provinsi Gorontalo tahun 2015, luas panen tanaman jagung sekitar 129.131 ha dengan produksi mencapai 643.512 ton.Untuk data dari setiap kabupaten, kabupaten dengan penghasil jagung terbanyak adalah kabupaten Pohuwato dengan luas panen sekitar 57.349 ha dengan produksi mencapai 309.088 ton.

Budidaya jagung di Gorontalo dilakukan pada lahan datar dan lahan miring (perbukitan). Berdasarkan hasil survey yang dilakukan oleh peneliti bersama Yanmar Riset Institut (YARI) tahun 2016 di kabupaten 
Pohuawato, lebih dari $60 \%$ tanaman jagung dibudidayakan di lahan miring. Jagung yang dibudidayakan pada lahan datar biasanya menghasilkan 7-9 ton/ha, namun ada juga yang mencapai 10-12 ton/ha (khusus jagung bisi 2).

Topografi lahan di provinsi Gorontalo yang berbukit-bukit menjadi salah satu factor sulitnya mendapatkan lahan datar untuk membudidayakan jagung. Untuk meningkatkan hasil tanaman jagung, maka petani membudidayakan jagung di daerah perbukitan. Jagung yang dibudidayakan di lahan miring biasanya menerapkan sistem TOT (Tanpa Olah Tanah), namun ada juga yang melakukan pengolahan tanah dengan menggunakan satu mata bajak singkal yang ditarik oleh sapi. Hasil panen jagung di lahan miring biasanya mencapai 2-4 ton/ha. Pertanian di lahan perbukitan biasanya berjarak 5-7 km dari pemukiman warga, dengan medan yang berat, karena harus menyusuri lembah, sungai dan bukit.

Jagung yang ditanam pada lahan miring hasilnya lebih sedikit dibandingkan lahan datar, namunkarenaketersediaanlahan yang luas, dan lahan tersebut hanya cocok untuk tanaman jagung, maka petani berupaya untuk membudidayakannya. Rerata luas lahan yang digarap oleh petani berkisar antara 1,2-2 ha, akan tetapi ada beberapa petani yang menggarap 20-40 ha. Pada umumnya penanaman jagung pada lahan perbukitan dapat tumbuh dengan baik, namun salah satu masalah yang dihadapi oleh petani adalah pada saat panen. Pemanenan jagung biasanya membutuhkan biaya yang lebih banyak dibandingkan dengan biaya penanaman dan perawatan. Biaya terbesar pada saat panen adalah pengangkutan jagung dari kebun hingga keperkampungan. Pengangkutan jagung dilakukan dengan menggunakan sepeda motor. Jagung yang diangkut kondisinya belum terpipil dan biayanya berkisar Rp 5.000 - Rp10.000/karung tergantung jarak pengangkutan dengan berat $50 \mathrm{~kg} / \mathrm{karung}$. Pada dasarnya sudah banyak rancangan mesin pemipil jagung baik yang semi mekanis (Rasid et al, 2014) dan mekanis (Supriono et al,2017) tetapi belum portable. Kondisi ini akan menyulitkan jika pemipilan dilakukan dilahan, disebabkan sulitnya membawa pemipil jagung kekebun karena dimensinya yang besar dan jaraknya yang jauh. Sementara itu, jika pemipilan dilakukan secara manual, pemilik kebun membutuhkan tenaga, waktu dan biaya yang banyak.

Berdasarkan uraian tersebut, salah satu solusi terbaik yang harus dilakukan untuk mengurangi biaya transportasi adalah mengangkut jagung dari kebun keperkampungan dalam kondisi sudah terpipil. Untuk melakukan pemipilan di kebun, diperlukan sebuah inovasi baru, berupa pemipil jagung yang portable, mudah dioperasikan, dan tepat guna bagi petani sehingga dapat meningkatkan pendapatan petani.

\section{METODE PENELITIAN \\ Alat dan Bahan}

Alat yang digunakan dalam penelitian ini dibagi dalam beberapa kategori yaitu alat perancangan, pabrikasi dan pengujian. Pada proses perancangan menggunakan alat berupa computer dan software gambar. Dalam membangun mesin pemipil digunakan separangkat alat dan mesin pabrikasi yang terdiri dari mesin las, mesin bubut dan peralatan pendukung lainnya. Proses pengujian mesin dilakukan secara ekperimental dengan mengatur kecepatan putaran mesin yang dikonversi ke komponen pemipil.

Bahan yang akan digunakan dibagi dalam dua kelompok yaitu bahan untuk pabrikasi dan pengujian. Bahan pabrikasi terdiri daribesisiku $3 \times 3 \mathrm{~cm}$, plat $2 \mathrm{~mm}$, puli, v-belt, pipabesi 4". Bahan pengujian terdiri dari bahan bakar penggerak motor dan jagung siap pipil.

\section{RancanganFungsional}

Komponen mesin terdiri dari kerangka sebagai penopang dan tempat melekatnya komponen-komponen utama mesin. Saluran pemasukan bahan (hopper) berfungsi sebagai saluran pemasukan bahan ke ruang pemipilan. Poros pemipil dan ruang pemipil berfungsi sebagai tempat proses pemipilan berlangsung dimana pemisahan biji jagung dilakuan dengan memanfaatkan putaran poros yang memberikan gaya gesek ke buah jagung dengan kisi-kisi sehingga biji jagung terlepas dari tongkolnya. Saluran pengeluaran tongkol dan biji berfungsi untuk mengeluarkan biji dan tongkol secara terpisah. Gambar 1 berikut menunjukkan bentuk bentuk dari bagianbagian yang dimaksudkan 


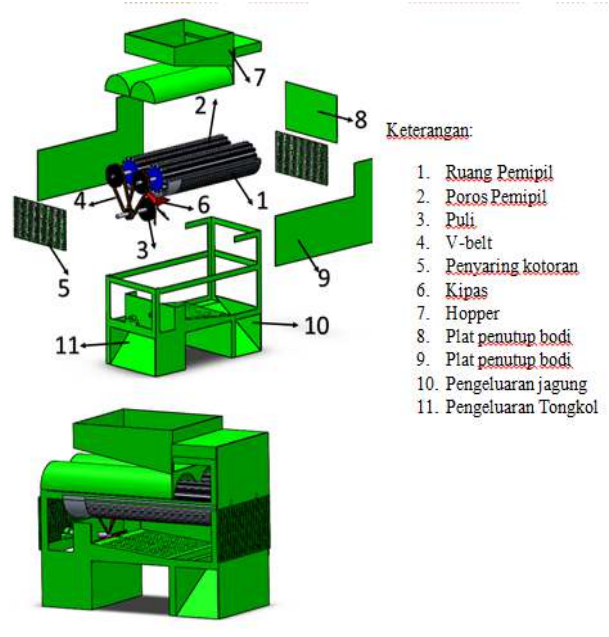

Gambar 1. komponen mesin pemipil

\section{RancanganStruktural}

\section{a. PerancanganPorosPemipil}

Poros yang dibuat merupakan kombinasi antara poros, pipa besi dan karet dari ban sepeda motor bekas. Dengan diameter keseluruhan $12 \mathrm{~cm}$. Diameter poros yang digunakan sebesar $1,25 \mathrm{~cm}$ yang dikombinasikan dengan pipabesi diameter 10 $\mathrm{cm}$. Poros tersebut akan dililit dengan besi beton membentuk ulir yang diselubungi dengan karet dengan ketebalan $1 \mathrm{~cm}$.

\section{b. PerancanganPulidan V-belt}

Pulidan V-belt merupakan komponen yang mentransmisikan daya dari sepeda motor. Untuk menurunkan putaran maka puli yang digunakan adalah puli $12 \mathrm{~cm}$ dan $6 \mathrm{~cm}$. Puli 6 $\mathrm{cm}$ akan dihubungkan pada poros engkol engine motor dengan menggunakan mur 17 mm. Panjang V-belt untuk pemipil dan poros kipas diperoleh 99,6 cm, sedangkan panjang V-belt dari engine keporos kipas yaitu $219 \mathrm{~cm}$.

\section{c. PerancanganHopper}

Hopper dibuat dari plat besi $2 \mathrm{~mm}$. Dimensinya $45 \times 40 \times 28 \mathrm{~cm}(\mathrm{p} \times 1 \times \mathrm{t})$. Bagian ini juga didesain bersamaan dengan bagian atas ruang pemipilan. Hopper ini dapat dibongkar pasang dan menggunakan system penghubung mur dan baut sebagai penahannya. Bagian ini juga memiliki ruang pemasukan sebesar $10 \times 40 \mathrm{~cm}(\mathrm{p} \times 1)$ dengan kemiringan alas $10^{\circ}$.

\section{d. Perancangansistem penggandengan}

Ide penelitian ini berasal dari pemanfaatan engine sepeda motor sebagai pompa air yang dikolaborasikan dengan sepeda motor yang menggunakan box guna untuk menyimpan barang bawaan. Dimensi alat yang rancang adalah $80 \times 40 \times 70 \mathrm{~cm}(\mathrm{p} \times$ $1 \times \mathrm{t}$ ). Tujuannya agar pengemudi lebih mudah dalam mengedarai motornya. Sistem penggandengan dapat dilihat pada gambar 2 berikut :

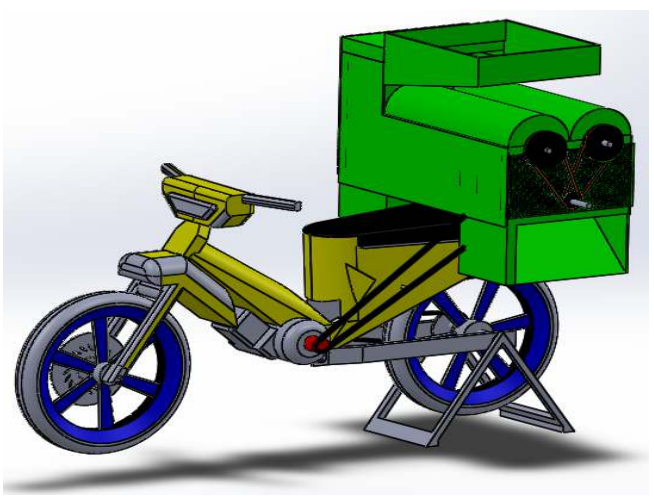

Gambar 2. sistem penggandengan mesin

\section{Prosedur Pengambilan dan Analisis Data a. Pengujian Fungsional}

Pada tahapan ini, pemipil jagung akan dilakukan pengujian untuk melihat kinerja dari bagian-bagian alat seperti yang telah dijelaskan pada sub-bab perancangan fungsional. Data yang diambil dari pengujian ini meliputi; kapasitas pemipilan, putaran engine, putaran poros.

\section{b. Kapasitas Pemipilan}

Jagung dimasukkan secara manual kedalam hopper. Jumlah jagung ditentukan beratnya sebesar $1,6 \mathrm{~kg} \mathrm{rpm}$ (yang sudah terkupas). Waktu yang digunakan selama melakukan sekali pemipilan, dihitung dengan menggunakan stopwatch. Jagung yang sudah dipipil, selanjutnya ditimbang untuk memperoleh berat jagung setelah dipipil. Nilai kapasitas pemipilan dihitung berdasarkan berat jagung terpipil $(\mathrm{kg})$ dibagi dengan waktu (jam). Selain kapasitas pemipilan, effisiensi pemipilan juga dihitung berdasarakan jumlah jagung terpipil dengan jumlah jagung yang masih melekat di tongkol. 


\section{c. Putaran Engine Dan PorosPemipil}

Putaran engine akan divariasikan, sehingga akan berpengaruh kecepatan pada poros pemipil. Variasi bertujuan untuk mencari putaran engine yang tepat untuk melakukan pemipilan. Terdapat tiga variasi kecepatan yakni $2000 \mathrm{rpm}$ - $3500 \mathrm{rpm}, 3501$ $\mathrm{rpm}-5000 \mathrm{rpm}$ dan $5001 \mathrm{rpm}-6500 \mathrm{rpm}$. Putaran engine akan diukur dengan menggunakan tachometer.

\section{HASIL DAN PEMBAHASAN}

\section{Kinerja Fungsional dan struktural mesin}

Dimensi pemipil jagung hasil rancangan terdiri dari panjang $80 \mathrm{~cm}$, lebar 40 $\mathrm{cm}$ dan tinggi $70 \mathrm{~cm}$. Secara umum mesin pemipil yang dirancangan mampu melakukan pemipilan jagung. Putaran mesin yang ditransmisikan dengan sistem puli dan v-belt dari mesin sepeda motor mampu memutar komponen pemipil yang terdiri dari dua poros yang berputar berlawanan arah. Kerangka mesin sebagai penopang keseluruhan komponen juga dalam kondisi stabil pada saat proses pemipilan berlangsung. Saluran pemasukan (Hopper) jagung dan saluran pengeluaran biji jagung dan tongkol juga mampu menjalankan fungsinya dengan baik. Gambar 3 berikut menunjukkan mesin pemipil jagung hasil rancangan yang sudah digandengkan dengan sepeda motor.

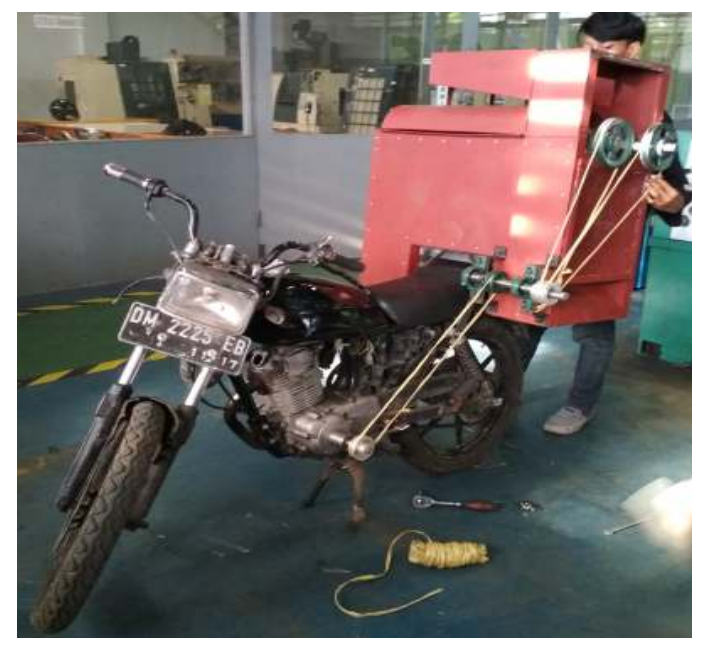

Gambar 3. Penggandengan mesin pemipil jagung pada sepeda motor

Proses pemipilan dimulai dengan memasukkan buah jagung melalui saluran pemasukan yang dilanjutkan ketahap pemipilan pada ruang pemipil. Mekanisme pemipilan terjadi dengan cara buah jagung akan memasuki celah yang terdapat pada dua poros pemipil yang berputar berlawanan arah. Poros pemipil yang dilengkapi dengan besi beton yang dililitkan menyerupai ulir pada poros akan memberikan gaya gesek yang memisahkan biji jagung dari tongkolnya. Biji jagung akan melewati kisi-kisi dibawah poros pemipil untuk teruskan ke saluran pengeluaran biji. Tongkol jagung dengan mekanisme screw conveyor yang terdapat pada poros pemipil akan membawa tongkol ke saluran pengeluran tongkol pada sisi yang berbeda dari saluran pengeluaran biji.

Permasalahan yang dihadapi pada proses pemipilan ini adalah masih ditemukannya jagung yang belum terpipil secara sempurna dan masih adanya biji jagung yang keluar dari saluran pengeluaran tongkol. Hal ini disebabkan oleh jarak ulir pada poros pemipil yang masih besar dan kecepatan putaran poros pemipil yang cukup tinggi yang menghasilkan momentum yang cukup besar dalam mengarahkan biji jagung ke saluran pengeluaran biji dan tongkol.

\section{Kecepatan pemipilan}

Hasil pengujian dengan melakukan proses pemipilan buah jagung dengan berat 1,6 $\mathrm{kg}$ menunjukkan bahawa kecepatan poros yang semakin tinggi menghasilkan waktu proses yang semakin singkat. Kecepatan poros pemipil dengan kisaran 5001-6500 rpm yang merupakan kecepatan perlakuan tertinggi menunjukkan waktu proses tersingkat yakni 12,76 detik. Berdasarkan pengujian waktu proses pemipilan akan menurun secara linear seiring dengan peningkatan kecapatan putaran poros pemipil. Gambar 4 berikut menunjukkan hubungan antara kecepatan poros pemipil dengan waktu pemipilan. 


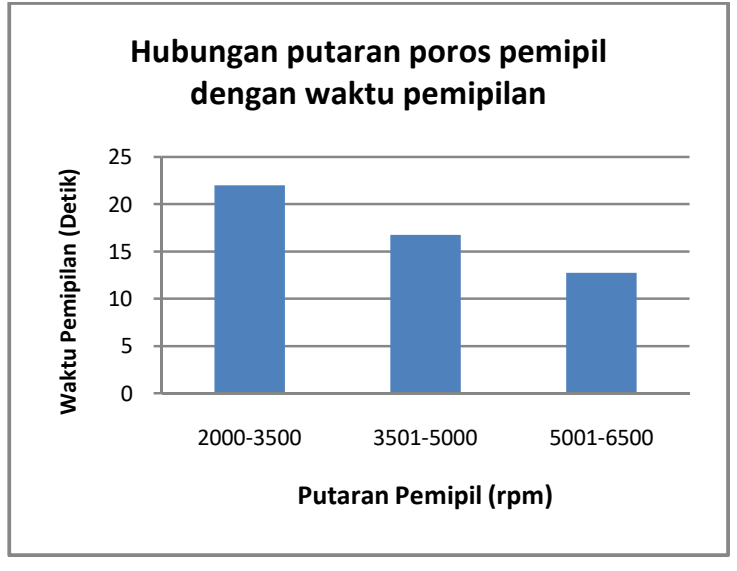

Gambar 4. hubungan putaran poros pemipil dengan waktu pemipilan

\section{Effisiensi Pemipilan}

Effisiensi pemipilan dari ketiga
perlakuan kecepatan peningkatan effisiensi pemipilan meskipun nilainnya tidak terlalu siknifikan. Kisaran effisiansi berada pada $77,6 \%-80,1 \%$, hal ini menunjukkan 19,9\%-22,4\% biji jagung masih melekat pada tongkolnya setelah proses pemipilan berlangsung dan keluar melalui saluran pengeluaran tongkol. Jumlah ini cukup besar dibandingkan dengan hasil penelitian yang sudah dilakukan sebesar $0,47 \%-0,58 \%$ (Firmansyah, 2011).Umumnya posisi biji jagung yang tidak terpipil berada pada ujung buah. Gambar 5 berikut menunjukkan hubungan antara kecepatan poros pemipil dengan effisiensi jagung terpipil.

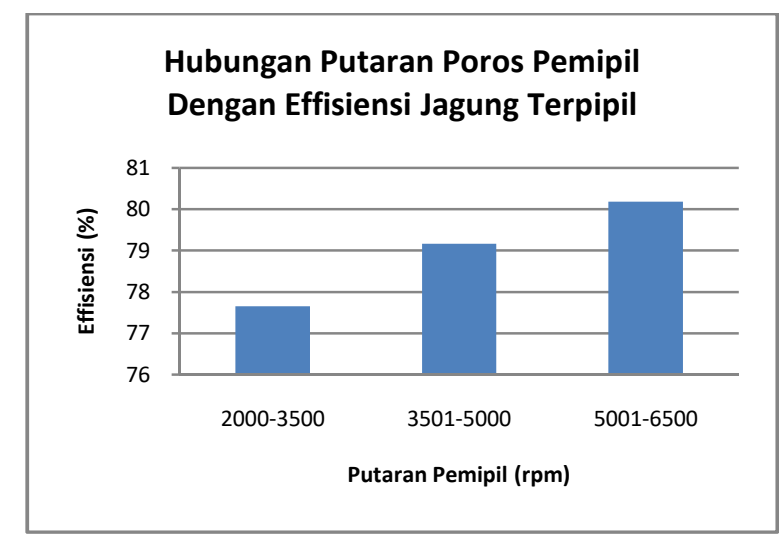

Gambar 5. Hubungan antara putaran poros pemipil dengan effisiensi jagung terpipil

Biji yang masih melekat pada tongkol disebabkan oleh bentuk geometris jagung yang menyerupai bentuk krucut. Posisi jagung pada saat pemipilan adalah melintang di celah antara kedua poros dengan kisi-kisi pemisah biji dan tongkol dimana celah ini tidak mengikuti bentuk geometris jagung. Kondisi ini menyebabkan biji jagung lebih mudah terpipil pada bagian pangkal dan bagian tengah jagung dibandingkan dengan biji pada bagian ujung. Penyebab lainnnya adalah besarnya gaya gesek yang disebabkan putaranan antara poros dan kisi-kisi yang mengakibatkan pecahnya tongkol jagung pada saat proses berlangsung sehingga memperkecil ukuran buah jagung yang mengakibatkan kesulitan pemipilan karena ukuranya lebih kecil dari ukuran celah antara poros dan kisikisi.

\section{Kapasitas pemipilan}

Peningkatan kecepatan poros pemipil berbanding lurus dengan kapasitas kerja pemipilan dimana kapasitas pemipalan dari putaran rendah, sedang dan cepat berturutturut sebesar 159,7 kg/jam, 191,3 kg/jam dan $282,84 \mathrm{~kg} / \mathrm{jam}$. Gambar 5 berikut menunjukkan hubungan antara putaran poros pemipil dengan kapasitas pemipilan.

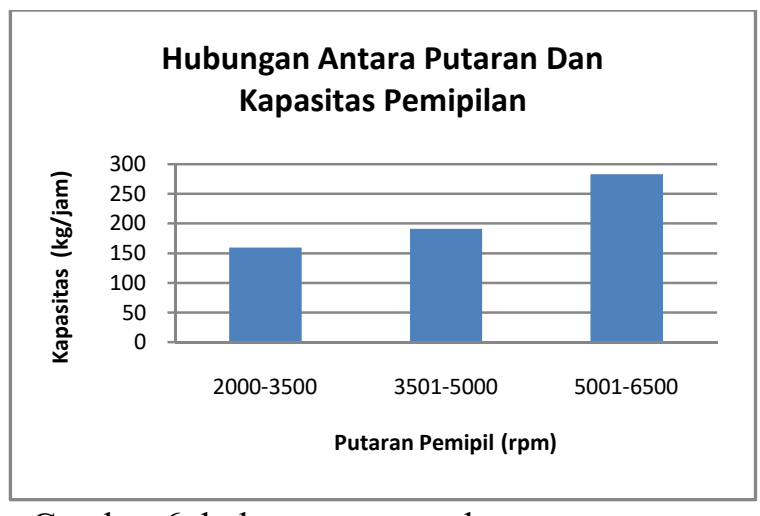

Gambar 6. hubungan antara kecepatan poros dengan kapasitas pemipilan

Kapasitas mesin pemipil ini lebih besar dibandingkan dengan kapasitas pemipilan yang dilakukan secara manual. Penelitian pendahuluan yang dilakukan untuk mencari besarnya kapasitas pemipilan secara manual dengan melibatkan 6 orang peserta dengan memipil jagung denga 6 kali ulangan dengan berat yang sama menunjukkan kapasitas pemipilan sebesar $8,4 \mathrm{~kg} / \mathrm{jam}$. 


\section{KESIMPULAN DAN SARAN}

\section{Kesimpulan}

Berdasarkan hasil penelitian dapat disimpulkan bahawa : 1) mesin pemipil jagung portable yang dirancang dengan memanfaatkan putaran mesin sepeda motor mampu bekerja secara fungsional dan struktural dalam memisahkan biji dati tongkol jagung. 2) Terdapat jagung yang tidak terpipil sebesar 19,9\%-22,4\% yang tedapat pada ujung buah. 3) Putaran poros pemipil dengan kecepatan tinggi yakni putaran poros pada kisaran 5001-6500 rpm menunjukkan performa terbaik dalam waktu proses, effisiensi pemipilan dan kapasitas pemipilan.

\section{Saran}

Diperlukan penelitian lebih lanjut dalam merancang ruang pemipil dengan mempertimbangkan bentuk geometri buah jagung dan besarnya kecepatan poros pemipil sehingga gaya gesek dan momentum dapat atur untuk menjaga kondisi buah tetap utuh serta pemisahan biji dan tongkol dapat dilakukan dengan baik.

\section{UCAPAN TERIMA KASIH}

Ucapan terimakasih peneliti sampaikan kepada Kementrian Riset dan Teknologi Republik Indonesia yang telah memberikan dana penelitian melalui skema Penelitian Dosen Pemula (PDP) 2018 dengan Nomor Kontrak 02/E.1/KPT/2017 dan kontrak dengan Direktur Politeknik Gorontalo nomor 112.e/PoltekGtlo.A2/LL/IV/2018

\section{DAFTAR PUSTAKA}

Firmansyah LU.2011.Pengujian Mesin Pemipil Jagung Model PJM4Balitseral di Petani. Balai Penelitian Tanaman Serealia. Seminar Nasional Serealia 2011.

Rasid NA, Lanya B, Tamrin. 2014. Modifikasi Alat Pemipil Jagung Semi Mekanis. Jurnal Teknik Pertanian Lampung Vol.3 No.2, Hal. 163172

Supriyono, Tri M, Agam CA. 2017. Desain Perancangan Mesin Pengolahan Jagung. Jurnal Teknik FTUP, Volume 30 Nomor 1 Februari 2017

Laporan Akhir Tahun Dinas Pertanian, Tanaman Pangan dan Hortikultura Provinsi Gorontalo, 2015

Laporan Yanmar Riset Institut (YARI) tahun 2016 di kabupaten Pohuawato 